\title{
THE EFFECTS OF THYROXIN AND GROWTH HORMONE ON LIVER POLYPLOIDY ${ }^{1}$
}

\author{
I. I. GESCHWIND, M. ALFERT AND C. SCHOOLEY ${ }^{2}$ \\ Hormone Research Laboratory, and Department of Zoology and its Cancer Research Genetics \\ Laboratory, University of California, Berkeley 4, California
}

Polyploidy in the cells of the hepatic parenchyma is known to be influenced by changes in the endocrine state produced by hypophysectomy and growth hormone administration (Di Stefano and Diermeier, 1956; Leuchtenberger, Helweg-Larsen and Murmanis, 1954). We have confirmed the effects of both the former (Geschwind, Alfert and Schooley, 1958) and the latter (see below) on liver polyploidy, but have shown that although the hormonal environment may normally play a role in the development of polyploidy, it is not indispensable to that development (Geschwind, Alfert and Schooley, 1958).

In the course of experiments designed to investigate the hormonal factors necessary to stimulate growth in the genetic dwarf mouse (Cole, Geschwind, and Bern, unpublished experiments), it was found that highly purified bovine growth hormone preparations were far less effective in stimulating body growth than were the crude preparations used for this purpose by F $\not$ nss-Bech (1947). Since contamination of the crude preparations with the thyrotropic hormone was strongly suspected, it was decided to investigate the effects of thyroxin (more readily available in pure form than is the thyrotropic hormone), alone and in combination with growth hormone, on body growth and liver polyploidy. The results of the experiments on liver polyploidy in these animals, together with the results of a similar series of experiments in the hypophysectomized rat, are reported below.

\section{Materials And Methods}

Male and female dwarf mice, 40 to 65 days of age, were apportioned into four groups, one of which served as a control group. The animals in each of the other groups were injected with either 50 micrograms twice weekly of dl-thyroxin (the dose suggested by Nielsen, 1953), 25 micrograms daily of a bovine growth hormone preparation or both hormones at the aforementioned dose levels. Injections were continued for 21 days. $^{3}$

Male rats of the Long-Evans strain were hypophysectomized at 28 days of age. One week later the animals were apportioned into four groups, one of which served as a control group. The animals in each of the other groups were injected with either 2 micrograms daily of 1-thyroxin, 25 micrograms daily of the bovine growth hormone preparation, or both hormones at these respective dose levels. Injections were continued for 22 days.

${ }^{1}$ Supported by University of California Cancer Funds.

2 With technical assistance from Charles Jordan and Norma O. Goldstein.

${ }^{3} \mathrm{We}$ gratefully acknowledge gifts of materials from the following: Dr. C. H. Li for the hormones and Beth Cole for the livers of the dwarf mice. 
All animals were sacrificed on the day after the last injection, and the hepatic left lateral lobes were removed from the anesthetized animals, sliced freehand, and fixed in acetic-alcohol. The procedure followed for the preparation of sections for counting and the actual counting procedures have been previously described (Alfert and Geschwind, 1958). Approximately 1000 parenchymal cells were scored in the sections obtained from each animal. The mean percentage distributions of the various types of hepatic parenchymal cells in each of the experimental groups in both series, along with the mean initial and terminal body weights of the animals in each group are recorded in Tables I and II.

\section{Results ANd Discussion}

In the genetic dwarf mouse, the administration of either growth hormone or thyroxin results in a decrease in the number of hepatic mononucleate diploid cells and an increase in tetraploid and binucleate cells (Table I). Of the two hormones, thyroxin, at the dose administered, appears to be more effective in producing these changes. By far the greatest effect, however, was observed in those animals receiving the combined hormone treatment. Such animals also showed the greatest weight gain during the period of injections.

It was difficult to determine unequivocally the manner by which thyroxin brought about its observed effect, since at least three different interpretations of the data could be advanced. One is that thyroxin enhanced polyploidization directly, either by acting as a specific mitogenic agent or by promoting the need for accelerated liver function. A second interpretation might be that the changes in the liver were simply the result of the administration of a large dose of a compound that had to be conjugated and metabolized by the liver, or that was toxic

TABLE I

The distribution of hepatic parenchymal cell types in control and experimental dwarf mice

\begin{tabular}{|c|c|c|c|c|c|c|c|}
\hline \multirow{2}{*}{ Group } & \multicolumn{2}{|c|}{ Body weight } & \multicolumn{5}{|c|}{ Mean percentage distribution of cell types* } \\
\hline & Initial & Terminal & $2 n$ & $2 \mathrm{n} \mathrm{bi}$ & $4 n$ & $4 \mathrm{n} \mathrm{bi}$ & $8 \mathrm{n}$ \\
\hline Control** & $\begin{array}{l}g . \\
6.1\end{array}$ & $\begin{array}{l}\text { g. } \\
7.1\end{array}$ & $\begin{array}{c}81.4 \\
(78.2-83.1) \dagger\end{array}$ & $\begin{array}{c}13.1 \\
(10.5-15.3)\end{array}$ & $\begin{array}{c}3.9 \\
(1.7-5.2)\end{array}$ & $\begin{array}{c}0.1 \\
(0.0-0.2)\end{array}$ & $\begin{array}{c}0.1 \\
(0.0-0.3)\end{array}$ \\
\hline Thyroxin & 6.5 & 10.0 & $\begin{array}{c}53.4 \\
(49.0-60.4)\end{array}$ & $\begin{array}{c}18.1 \\
(12.2-23.7)\end{array}$ & $\begin{array}{c}24.3 \\
(21.9-26.1)\end{array}$ & $\begin{array}{c}3.0 \\
(1.4-4.8)\end{array}$ & $\begin{array}{c}0.1 \\
(0.0-0.2)\end{array}$ \\
\hline Growth hormone & 7.1 & 10.3 & $\begin{array}{c}69.0 \\
(65.4-70.9)\end{array}$ & $\begin{array}{c}20.9 \\
(17.0-23.2)\end{array}$ & $\begin{array}{c}8.1 \\
(4.1-10.3)\end{array}$ & $\begin{array}{c}0.9 \\
(0.6-1.1)\end{array}$ & 0.0 \\
\hline $\begin{array}{l}\text { Thyroxin }+ \\
\text { growth hormone }\end{array}$ & 6.2 & 12.1 & $\begin{array}{c}31.6 \\
(23.4-37.9)\end{array}$ & $\begin{array}{c}8.6 \\
(5.6-10.2)\end{array}$ & $\begin{array}{c}52.8 \\
(45.7-61.7)\end{array}$ & $\begin{array}{c}4.2 \\
(3.3-5.7)\end{array}$ & $\begin{array}{c}1.6 \\
(1.0-2.3)\end{array}$ \\
\hline
\end{tabular}

* $2 \mathrm{n}=$ diploid $; 2 \mathrm{n}$ bi $=$ diploid binucleate $; 4 \mathrm{n}=$ tetraploid $; 4 \mathrm{n}$ bi $=$ tetraploid binucleate $8 \mathrm{n}=$ octaploid. (In all experiments approximately $1 \%$ of the cells could not be classified.)

** Three animals per group.

$\dagger$ Range of individual results. 
TABLE II

The distribution of hepatic parenchymal cell types in control and experimental hypophysectomized rats

\begin{tabular}{|c|c|c|c|c|c|c|c|}
\hline \multirow{2}{*}{ Group } & \multicolumn{2}{|c|}{ Body weight } & \multicolumn{5}{|c|}{ Mean percentage distribution of cell types* } \\
\hline & Initial & Terminal & $2 \mathrm{n}$ & $2 \mathrm{n} \mathrm{bi}$ & $4 \mathrm{n}$ & $4 \mathrm{n} \mathrm{bi}$ & $8 \mathrm{n}$ \\
\hline Control** & $\begin{array}{c}g \\
74\end{array}$ & $\begin{array}{l}g \\
82\end{array}$ & $\begin{array}{c}70.1 \\
(67.3-74.5) \dagger\end{array}$ & $\begin{array}{c}24.0 \\
(20.6-26.5)\end{array}$ & $\begin{array}{c}4.8 \\
(4.1-5.8)\end{array}$ & $\begin{array}{c}0.2 \\
(0.1-0.4)\end{array}$ & 0.0 \\
\hline Thyroxin & 77 & 93 & $\begin{array}{c}52.3 \\
(46.6-57.8\end{array}$ & $\begin{array}{c}24.0 \\
(18.1-26.9)\end{array}$ & $\begin{array}{c}22.0 \\
(19.4-24.6)\end{array}$ & $\begin{array}{c}0.7 \\
(0.1-1.1)\end{array}$ & $\begin{array}{c}0.1 \\
(0.0-0.2)\end{array}$ \\
\hline Growth hormone & 74 & 103 & $\begin{array}{c}53.2 \\
(50.7-58.1)\end{array}$ & $\begin{array}{c}24.0 \\
(19.9-29.6)\end{array}$ & $\begin{array}{c}20.6 \\
(17.3-23.6)\end{array}$ & $\begin{array}{c}0.8 \\
(0.1-1.2)\end{array}$ & $\begin{array}{c}0.1 \\
(0.0-0.4)\end{array}$ \\
\hline $\begin{array}{l}\text { Thyroxin }+ \\
\text { growth hormone }\end{array}$ & 72 & 123 & $\begin{array}{c}22.1 \\
(19.8-26.3)\end{array}$ & $\begin{array}{c}9.5 \\
(6.4-14.7)\end{array}$ & $\begin{array}{c}61.4 \\
(56.0-68.1)\end{array}$ & $\begin{array}{c}3.9 \\
(2.4-6.2)\end{array}$ & $\begin{array}{c}1.9 \\
(1.6-2.1)\end{array}$ \\
\hline
\end{tabular}

$*, * *, \dagger$ Symbols have the same meaning as in Table I.

to the parenchymal cells in the dosage employed. Finally, it was possible that thyroxin, in its capacity as a hormone, promoted repair of pituitary acidophiles which are normally absent in the dwarf mouse (Ortman, 1956), and by so doing stimulated growth hormone secretion. There is good evidence that thyroxin repairs pituitary acidophile cytology in the thyroidectomized rat (Koneff, Scow, Simpson, Li and Evans, 1949; Contopoulos, Simpson and Koneff, 1958), and concomitantly restores growth activity (Eartley and Leblond, 1954; Contopoulos et al., 1958). Such an effect on the acidophiles could explain the findings of Carrière (1955) that in the thyroidectomized rat, hepatic nuclei with diameters of only $6.0 \mu$ are found after a considerable post-operative interval, whereas in normal controls or in thyroidectomized animals treated with growth hormone, thyroxin, or both, nuclei with diameters of 6.5 and $8.0 \mu$ are seen. The probability that growth hormone secretion is depressed after thyroidectomy could also explain our own unpublished findings that in animals which had been thyroidectomized at 24 days of age, the distribution of hepatic parenchymal cell types found at 114 days was that characteristic of 40- to 45-day-old animals. The change, in the normal animal, in the distribution of cell types with age has been previously reported (Alfert and Geschwind, 1958).

In order to eliminate the possibility that thyroxin was acting to enhance polyploidization by repairing pituitary function, experiments were conducted in hypophysectomized rats. Such animals have a further advantage of being far more sensitive to thyroxin than is the dwarf mouse, permitting a much smaller dose of thyroxin to be employed ( 2 micrograms daily to a rat weighing 75 grams versus 50 micrograms twice weekly to a mouse weighing 6 grams). Thus, any effects due to conjugation and metabolism by the liver, or to toxicity, are minimized.

The results of these experiments (Table II) reveal that the effect of thyroxin on the hypophysectomized rat is comparable, at the dose levels chosen, to that 
obtained with growth hormone. In both cases a 25\% decrease in the number of mononucleate diploid cells has occurred, along with a 5 -fold increase in the number of tetraploid cells. As in the case of the dwarf mouse, the greatest effect, however, was found in those animals receiving both hormones, for in the livers of such animals the total number of diploid cells was only one-third that found in the control animals, while the numbers of both tetraploid and octaploid cells increased markedly. The synergistic effect of the two hormones administered together is also reflected in the body weight increments of the treated animals.

These experiments therefore indicate that thyroxin (and presumably thyrotropic hormone) as well as growth hormone contributes to the hormonal environment which affects the development of hepatic polyploidy. It should also be noted that thyroxin alone can be at least as efficient as growth hormone in promoting the progression of hepatic polyploidy; thus, as we also have demonstrated by the results of a previous experiment (Geschwind, Alfert and Schooley, 1958), the suggestion of Leuchtenberger et al. (1954), concerning the supposed essential role of growth hormone in somatic polyploidy, cannot be maintained.

\section{SUMMARY}

1. The effect of thyroxin and of growth hormone on liver polyploidy has been investigated in the dwarf mouse and in the hypophysectomized rat.

2. Either hormone, acting alone, stimulated polyploidization in these experimental animals; the combination of both hormones synergized to produce an hepatic cell picture dominated by higher polyploid classes.

\section{LITERATURE CITED}

Alfert, M., And I. I. Geschwind, 1958. The development of polysomaty in rat liver. Exp. Cell Res., 15 : 230-232.

CARRIÈRE, R., 1955. Influence of growth hormone and thyroxine on nuclear size in rat liver. Anat. Rec., 121: 273.

Contopoulos, A. N., M. E. Simpson And A. A. Koneff, 1958. Pituitary function in the thyroidectomized rat. Endocrinology, 63: 642-653.

Di Stefano, H. S., and H. F. Diermeier, 1956. Effects of hypophysectomy and growth hormone on ploidy distribution and mitotic activity of rat liver. Proc. Soc. Exp. Biol. Med., $92:$ : 590-594.

Eartley, H., And C. P. Leblond, 1954. Identification of the effects of thyroxine mediated by the hypophysis. Endocrinology, 54: 249-271.

Fønss-BECH, P., 1947. A study on growth hormone of anterior pituitary lobe. Ejnar Munksgaard, Copenhagen, 1947.

Geschwind, I. I., M. Alfert and C. Schooley, 1958. Liver regeneration and hepatic polyploidy in the hypophysectomized rat. Exp. Cell Res., 15: 232-235.

Koneff, A. A., R. O. Scow, M. E. Simpson, C. H. Li and H. M. Evans, 1949. Response by the rat thyro-parathyroidectomized at birth to growth hormone and to thyroxin given separately or in combination. II. Histological changes in the pituitary. Anat. Rec., 104 : 465-475.

Leuchtenberger, C., H. Fr. Helmeg-Larsen and L. Murmanis, 1954. Relationship between hereditary pituitary dwarfism and formation of multiple desoxyribose nucleic acid (DNA) classes in mice. Lab. Invest., 3: 245-260.

Nielsen, E. L., 1953. Studies on hereditary dwarfism in mice. XIV. Effect of thyroxin and growth hormone on growth. Acta Path. Microbiol. Scand., 32: 316.

Ortman, R., 1956. A study of some cytochemical reactions and of the hormone content of the adenohypohysis in normal and in genetic dwarf mice. J. Morph., 99: 417-432. 


\section{$2 \mathrm{BHL}$ Biodiversity Heritage Library}

Geschwind, Irving I., Alfert, Max, and Schooley, C. 1960. "The effects of thyroxin and growth hormone on liver polyploidy." The Biological bulletin 118, 66-69. https://doi.org/10.2307/1539056.

View This Item Online: https://www.biodiversitylibrary.org/item/110976

DOI: https://doi.org/10.2307/1539056

Permalink: https://www.biodiversitylibrary.org/partpdf/2121

\section{Holding Institution}

Smithsonian Libraries

\section{Sponsored by}

Biodiversity Heritage Library

\section{Copyright \& Reuse}

Copyright Status: In copyright. Digitized with the permission of the rights holder.

License: http://creativecommons.org/licenses/by-nc-sa/3.0/

Rights: https://biodiversitylibrary.org/permissions

This document was created from content at the Biodiversity Heritage Library, the world's largest open access digital library for biodiversity literature and archives. Visit BHL at https://www.biodiversitylibrary.org. 